\title{
Fertilizer Calibrations for Hybrid Brinjal based Cropping Sequence using Post-Harvest Soil Test Values Prediction Equations under Soil Test Crop Response Based Integrated Plant Nutrition System
}

\author{
Ch. Kirankumar ${ }^{1 *}$, R. Santhi ${ }^{2}$, D. Srihari ${ }^{3}$ and S. Maragatham ${ }^{1}$ \\ ${ }^{1}$ Department of Soil Science and Agricultural Chemistry, ${ }^{2}$ Directorate of Natural Resource \\ Management, Tamil Nadu Agricultural University, Coimbatore \\ ${ }^{3}$ Dr. YSR Horticultural University, Venkataramannagudem, Andhra Pradesh, India \\ *Corresponding author
}

\begin{tabular}{|l|}
\hline Key w or d s \\
$\begin{array}{l}\text { STCR-IPNS, } \\
\text { Inceptisol, PHSTVs } \\
\text { prediction } \\
\text { equations, Hybrid } \\
\text { brinjal }\end{array}$ \\
\hline Article Info \\
\hline $\begin{array}{l}\text { Accepted: } \\
\text { 15 June } 2019 \\
\text { Available Online: } \\
\text { 10 July } 2019\end{array}$ \\
\hline
\end{tabular}

A B S T R A C T

Field experiments were conducted with hybrid brinjal under IPNS during 2017-18 adopting Inductive cum Targeted yield model (Ramamoorthy et al, 1967) to develop postharvest soil test values (PHSTVs) prediction equations on Visakhapatnam soil series (TypicHaplustept) which is rednon-calcareous. The experiment was laid out in a fractional factorial design comprising twenty four treatments and the test crop experiment with hybrid brinjal was conducted with four levels of each of $\mathrm{N}\left(0,80,160\right.$ and $\left.240 \mathrm{~kg} \mathrm{ha}^{-1}\right)$, $\mathrm{P}_{2} \mathrm{O}_{5}\left(0,40,80\right.$ and $\left.120 \mathrm{~kg} \mathrm{ha}^{-1}\right)$ and $\left(0,60,120\right.$ and $\left.180 \mathrm{~K}_{2} \mathrm{O} \mathrm{kg} \mathrm{ha}{ }^{-1}\right)$ and three levels of FYM $\left(0,12.5\right.$ and $\left.25 \mathrm{t} \mathrm{ha}^{-1}\right)$. The IPNS treatments were superimposed across the strips. There were 21 fertiliser treatments along with three controls which were randomized in each strip in such a way that all the treatments occurred in both directions. Using the plot wise initial test values, fertiliser doses and fruit yield and /or uptake of N, P \& K by brinjal and post-harvest soil test values, PHSTVs prediction equations were developed. Both the predicted and observed soil test values revealed that the soil fertility was found to decline markedly under unfertilized (control) and increased based on fertiliser doses imposed and soil fertility gradient. Significant $\mathrm{R}^{2}$ values were recorded for these regression equations which could be used with confidence for the prediction of post-harvest $\mathrm{KMnO}_{4}-\mathrm{N}$, Olsen $\mathrm{P}$ and $\mathrm{NH}_{4} \mathrm{OAc}-\mathrm{K}$. Using the predicted PHSTVs of hybrid brinjal soil test based fertiliser prescriptions for desired yield targets of any succeeding crop could be prescribed.

\section{Introduction}

Soil test crop response correlation studies help in making fertiliser prescription for desired yield of crops and such studies are crop, soil and climate specific. The soil test calibration and fertiliser prescription must be based on yield which should provide significant correlation between soil test and crop response to fertiliser. Soil testing has to be rechristened as soil quality assessment and it has to assume a holistic role not limited to guide fertiliser prescription for a crop based on soil test but also for a sustainable crop production. Nutrient availability in soil after the harvest of a crop is much influenced by 
initial soil nutrient status, the amount of fertiliser nutrients added and nature of crop raised. To apply soil test based fertiliser prescriptions for a cropping sequence, the soils are to be tested after each crop, which is not practicable. Therefore, it has become necessary to predict the soil test values after the harvest of the first crop in a sequence which can be done by developing prediction equations. This provides the way for computing the fertiliser prescriptions for a whole cropping sequence based on initial soil test values. This is very useful because the soil of farmer' field under intensive cultivation cannot be tested for each crop for practical reasons. With this background, in the present study, an attempt has been made to predict the post-harvest soil test values for hybrid brinjal so as to prescribe soil test based fertiliser prescriptions for desired yield targets of any succeeding crop after the harvest of hybrid brinjal on Inceptisol of Andhra Pradesh.

\section{Materials and Methods}

Field experiments were conducted on a Visakhapatnam soil series (Typic Haplustept) of North Coastal zone of Andhra Pradesh at the Farm of College of Horticulture, Parvathipuram, Dr.YSR Horticultural University. The soil of the experimental field is well drained and sandy loam in texture. The initial soil $\mathrm{pH}$, electrical conductivity, organic carbon, available nitrogen $\left(\mathrm{KMnO}_{4}{ }^{-}\right.$ $\mathrm{N}$ ), available phosphorus (Olsen-P), available potassium $\left(\mathrm{NH}_{4} \mathrm{OAc}-\mathrm{K}\right)$ were $7.38,0.35$ $\mathrm{dSm}^{-1}, 5.8 \mathrm{~g} \mathrm{~kg}^{-1}, 212 \mathrm{~kg} \mathrm{ha}^{-1}, 26.0 \mathrm{~kg} \mathrm{ha}^{-1}$ and $240 \mathrm{~kg} \mathrm{ha}^{-1}$, respectively. Field experiments were carried out in two phases viz., fertility gradient and test crop experiment as per technical programme of STCR in fractional factorial design comprising twenty four treatments and test crop experiment with hybrid brinjal was conducted with four levels of $\mathrm{N}\left(0,80,160\right.$ and $\left.240 \mathrm{~kg} \mathrm{ha}{ }^{-1}\right), \mathrm{P}_{2} \mathrm{O}_{5}$ $\left(0,40,80\right.$ and $\left.120 \mathrm{~kg} \mathrm{ha}^{-1}\right)$ and $\mathrm{K}_{2} \mathrm{O}(0,60,120$ and $180 \mathrm{~kg} \mathrm{ha}^{-1}$ ) and three levels of farm yard manure (FYM - 0,12.5 and $25 \mathrm{t} \mathrm{ha}^{-1}$ ). The initial and post-harvest soil samples were collected from each fertility strip after hybrid brinjal and analysed for alkaline $\mathrm{KMnO}_{4}-\mathrm{N}$ (Subbaiah and Asija, 1956), Olsen -P (Olsen et al., 1954) and $\mathrm{NH}_{4} \mathrm{OAc}-\mathrm{K}$ (Hanway and Heidal, 1952).

Fruit and stalk samples were collected, processed and analysed for $\mathrm{N}, \mathrm{P}$ and $\mathrm{K}$ contents (Piper, 1966) and NPK uptake was computed. Crop was grown to maturity and plot wise fruit yield was recorded periodically and stalk weight was recorded at the end of growing period.

\section{Development of prediction equations for post-harvest soil test values}

The post-harvest soil test values were predicted by multiple regression equations, which were obtained by statistical evaluation by function of initial soil test values, applied fertiliser nutrient and fruit yield and/or the uptake of NPK by the crop were used as dependent variable and the post-harvest soil test values (independent variable) were used(Ramamoorthy,1971).

The functional relationship is as follows:

PHS $=\mathrm{f}(\mathrm{F}, \mathrm{ISTV}$, yield /nutrient uptake $)$

Where, $\mathrm{PHS}=$ Post - harvest soil test value; $\mathrm{F}=$ Applied fertiliser nutrient; ISTV= Initial soil test value of available $\mathrm{N}, \mathrm{P}$ and $\mathrm{K}$.

Mathematical form of equation is, YPHS= $\mathrm{a}+\mathrm{b}_{1} \mathrm{~F}+\mathrm{b}_{2} \mathrm{ISTV}+\mathrm{b}_{3}$ yield/uptake

Where, $a=$ absolute constant and $b_{1}$ and $b_{2}$ and $\mathrm{b}_{3}=$ Respective regression coefficients.

Using these regression equations, the postharvest soil test values of nitrogen, phosphorus and potassium were predicted after hybrid brinjal. 


\section{Results and Discussion}

Under intensive cropping, soil testing between two seasons becomes difficult in terms of time, money and labour. At this juncture, the prediction of post-harvest soil fertility (Ramamoorthy et al., 1971) developed using the initial soil test values, fertiliser doses and yield or uptake by the crop gains practical significance for making fertiliser prescriptions for the whole cropping sequence. The predicted post-harvest soil test values serve as the initial soil test values for the succeeding crop in the sequence and can be used for computing the fertiliser doses for any desired yield targets of the succeeding crop.

Following the methodology outlined by Ramamoorthy et al., (1971), PHSTVs prediction equations were developed for the prediction of post - harvest soil test values after the harvest of hybrid brinjal and are furnished in Table 1 along with the concerned $\mathrm{R}^{2}$ values. The results indicated that in case of prediction of $\mathrm{KMnO}_{4}-\mathrm{N}$, when hybrid brinjal yield was considered 96.64, 98.41 and 97.46 per cent of variations were accounted; while predictability values were 97.00,98.56 and 97.00per cent when nitrogen uptake is considered in NPK alone, NPK+FYM@12.5 t $\mathrm{ha}^{-1}$ and NPK+FYM@ $25 \mathrm{t} \mathrm{ha}^{-1}$ treatments respectively. For the purpose of comparison, the observed and predicted data based on yield and uptake for a set of selected treatments is furnished in Table 2. The observed mean $\mathrm{KMnO}_{4}-\mathrm{N}$ was $226.2 \mathrm{~kg}$ ha while mean predicted value using fruit yield and uptake were 231.4 and $232.1 \mathrm{~kg} \mathrm{ha}^{-1}$ respectively. The mean variation between observed and predicted value were5.2 and $5.9 \mathrm{~kg} \mathrm{ha}{ }^{-1}$ while fruit yield and uptake respectively used.

With respect to the prediction of Olsen-P, when yield was used, the extent of predictability was $94.24,97.53$ and 93.79 per cent and 94.09, 97.47 and 93.85 per cent while uptake of phosphorus was used in the case of NPK alone, NPK+FYM@ $12.5 \mathrm{t} \mathrm{ha}^{-1}$ and NPK+FYM @25 t ha ${ }^{-1}$ treatments respectively (Table 2). The observed mean Olsen $-\mathrm{P}$ value was $32.4 \mathrm{~kg} \mathrm{ha}^{-1}$, while mean predicted value using fruit yield and uptake were 34.2 and $34.3 \mathrm{~kg} \mathrm{ha}^{-1}$ respectively. The mean variation between observed and predicted value were 1.8 and $1.9 \mathrm{~kg} \mathrm{ha}^{-1}$ while fruit yield and uptake were respectively used.

Similarly in the case of $\mathrm{NH}_{4} \mathrm{OAc}-\mathrm{K}$, the predictability were $94.93,97.69$ and 98.47 per cent while yield was used and 94.91, 97.69 and 98.54 per cent when potassium uptake was used for the prediction of post-harvest soil nutrient status while considering NPK alone, NPK+FYM @ $12.5 \mathrm{t} \mathrm{ha}^{-1}$ and $\mathrm{NPK}+\mathrm{FYM} @ 25 \mathrm{t} \mathrm{ha}^{-1}$ treatments respectively (Table 2). The observed mean $\mathrm{NH}_{4} \mathrm{OAc}-\mathrm{K}$ value was $248.7 \mathrm{~kg} \mathrm{ha}^{-1}$ while the mean predicted value using fruit yield of hybrid brinjal is 251.7 and uptake was 251.9 $\mathrm{kg} \mathrm{ha}{ }^{-1}$ respectively. The mean variation between observed and predicted value was 3.0 and $3.2 \mathrm{~kg} \mathrm{ha}^{-1}$ while fruit yield and uptake were respectively used.

The results clearly indicated that both observed and predicted soil test values of available $\mathrm{N}, \mathrm{P}$ and $\mathrm{K}$ were in good agreement with each other, proving the validity of the post-harvest soil test values. Prediction equations as evidenced by highly significant correlation $\left(\mathrm{r}=0.97^{* *}\right),\left(\mathrm{r}=0.95^{* *}\right)$ and $(\mathrm{r}=$ $\left.0.97^{* *}\right)$ respectively for yield as well as uptake.

The difference between predicted and observed soil test values for the treated plots (five plots in each strip) were found to be very negligible and agree very closely. Analysis for available N, P and $\mathrm{K}$ also indicated highly significant relationship with high $\mathrm{R}^{2}$ value and fall in category of good fit in present study taking a value of $\mathrm{R}^{2}$ above 0.65 as 
criterion for good fit and value of $\mathrm{R}^{2}$ between 0.45 and 0.65 as moderate fit (Anon, 1973). The $\mathrm{R}^{2}$ values suggested that the prediction equations could be used with confidence for the prediction of available $\mathrm{N}, \mathrm{P}$ and $\mathrm{K}$ after the harvest of hybrid brinjal to make the soil test based fertiliser recommendations for any succeeding crop.

The prediction equations developed after hybrid brinjal can be used for prescribing fertiliser doses for any succeeding crop after hybrid brinjal. The predicted post-harvest soil test values of brinjal would become the initial soil test values for the succeeding crop. Thus the prediction equations developed can be used to assess the post -harvest soil fertility at the end of the crop and would be useful in giving fertiliser recommendations for the cropping sequence as a whole from initial soil test values. Such type of prediction equations were reported by Chandrasekhar Rao and Singh (1992) for maize -wheat and maizewheat-moong sequence, Andi (1998) for sunflower-bhendi sequence in Inceptisol, Coumaravel et al., (2013) for maize-tomato sequence, Praveena et al., (2013) for cotton based sequence, Dey and Das (2014) for rice -wheat, rice-maize and rice-rice sequences, Sarvesh Kumar et al., (2018) in turmeric in Mollisol and AlkaArya et al., 2019 for cauliflower in Mollisol.

Accordingly in the present investigation, the soil test values for $\mathrm{KMnO}_{4}-\mathrm{N}$, Olsen-P and $\mathrm{NH}_{4} \mathrm{OAc}-\mathrm{K}$ were compared with observed values (actually tested).

Figure 1 and 2 showed that the comparison between observed and predicted soil test values of available $\mathrm{N}, \mathrm{P}$ and $\mathrm{K}$ after brinjal using regression line wherein all points stayed close to the regression line and values were in good agreement with each other as evidenced by highly significant correlation $(\mathrm{r}=0.97 * *$, $0.97 * *$ and $0.99 * *$ respectively with both yield and uptake). Similar method of comparison between the observed and predicted data was also reported by Timsina et al., 1998; Sarvesh Kumar et al., (2018), Praveena Katharine et al., (2013).

From the results obtained for brinjal, both observed and predicted soil test values were in good agreement proving the validity of the post-harvest soil test values prediction equations which was also exhibited in the $1: 1$ regression line with highly significant ' $r$ ' values.

Fertiliser recommendations for desired yield targets for hybrid brinjal based on initial soil test values

Using the fertiliser prescription equations (FPEs) for hybrid brinjal and initial soil test values of available $\mathrm{N}, \mathrm{P}$ and $\mathrm{K}(212: 26: 240 \mathrm{~kg}$ $\mathrm{ha}^{-1}$ ), fertiliser recommendations were computed for a range of yield target under NPK alone and IPNS (NPK+FYM @ 12.5 and $\left.25 \mathrm{t} \mathrm{ha}^{-1}\right)$. The post-harvest soil test values were predicted using the PHSTVs prediction equations for hybrid brinjal.

A perusal of the data in Table 3 , showed that the quantity of fertilisers required to produce 50,55 and $60 \mathrm{t} \mathrm{ha}^{-1}$ of fruit yield was 170, 208 and $245 \mathrm{kgNha}^{-1}$; 93, 110 and $127 \mathrm{~kg} \mathrm{P}_{2} \mathrm{O}_{5}$ $\mathrm{ha}^{-1}$ and 112, 139 and $167 \mathrm{~kg} \mathrm{~K} \mathrm{O} \mathrm{ha}^{-1}$, respectively under NPK alone. When FYM @ 12.5 $\mathrm{t} \mathrm{ha}^{-1}$ along with fertilisers, the fertiliser requirements were 134,172 and 209 $\mathrm{kg} \mathrm{N} \mathrm{ha}{ }^{-1} ; 73,90$ and $107 \mathrm{~kg} \mathrm{P}_{2} \mathrm{O}_{5} \mathrm{ha}^{-1}$ and 83,110 and $138 \mathrm{~kg} \mathrm{~K}_{2} \mathrm{O} \mathrm{ha}{ }^{-1}$. When FYM @ $25 \mathrm{t} \mathrm{ha}^{-1}$ along with fertilisers 98,136 and 173 $\mathrm{kg} \mathrm{N}$ ha $^{-1}$; 53, 65 and $87 \mathrm{~kg} \mathrm{P}_{2} \mathrm{O}_{5} \mathrm{ha}^{-1}$ and 54,81 and $109 \mathrm{~kg} \mathrm{~K}_{2} \mathrm{O} \mathrm{ha}^{-1}$.

The predicted post-harvest soil test values were 227,231 and $234 \mathrm{~kg} \mathrm{ha}^{-1}$ of $\mathrm{KMnO}_{4}-\mathrm{N}$; $32.1,33.6$ and $35.0 \mathrm{~kg} \mathrm{ha}^{-1}$ Olsen-P and 247,252 and $255 \mathrm{~kg} \mathrm{ha}^{-1} \quad \mathrm{NH}_{4} \mathrm{OAc}-\mathrm{K}$ respectively, under NPK alone for 50,55 and $60 \mathrm{t} \mathrm{ha}^{-1}$ of yield targets of hybrid brinjal. 
Table.1 Prediction equations for post-harvest soil test values (PHSTVs) of available N, P and K for hybrid brinjal

\section{PHSTVs Prediction Equations}

$\mathbf{R}^{2}$

\section{NPK alone}

YPHN $=19.19+0.86739 * \mathrm{SN}+0.07638 * \mathrm{FN}+0.00021 * *$ fruit yield $0.9664 * *$

YPHN $=28.67+0.79726 * * \mathrm{SN}+0.06024 * * \mathrm{FN}+0.10926 * *$ uptake $0.9700 * *$

YPHP $=-\mathbf{0 . 8 8}+0.915536 * \mathrm{SP}+0.07157 * * \mathrm{FP}+0.00005 * *$ fruit yield $0.9424 * *$

$\mathrm{YPHP}=0.28+0.90378 * \mathrm{SP}+0.07608 * * \mathrm{FP}+0.04618 * *$ uptake $0.9409 * *$

YPHK $=4.52+0.93725 *$ SK $+0.12496 * *$ FK $+0.00007 * *$ fruit yield $0.9493 * *$

YPHK $=4.10+0.93544 *$ SK $+0.12735 * *$ FK $+0.03022 * *$ uptake $0.9491 * *$

NPK+FYM @ 12.5 tha $^{-1}$

YPHN $=13.77+0.89581 * * \mathrm{SN}+0.081324 * * \mathrm{FN}+0.000203 * *$ fruit yield $0.9841 * *$

YPHN $=14.20+0.902261 *$ SN $+0.089505 * * \mathrm{FN}+0.038516 * *$ uptake $0.9856^{* *}$

$\mathrm{YPHP}=-6.66+1.02000 * \mathrm{SP}+0.08814 * * \mathrm{FP}+0.00009 * *$ fruit yield $0.9753 * *$

YPHP $=-5.28+0.92186 * * \mathrm{SP}+0.08370 * * \mathbf{F P}+0.21472 * *$ uptake $0.9747 * *$

YPHK $=2.13+0.93797 *$ SK $+0.11859 * *$ FK $+0.00020 * *$ fruit yield $0.9769 * *$

YPHK $=-2.30+0.94231 *$ SK $+0.12196 * *$ FK $+0.08977 * *$ uptake $0.9758 * *$

NPK+FYM@ $25 \mathrm{t} \mathrm{ha}^{-1}$

YPHN $=13.26+0.85876 *$ SN $+0.07309 * * \mathbf{F N}+0.00043 * *$ fruit yield $0.9746 * *$

YPHN $=14.56+0.911314 *$ SN $+0.10580 * *$ FN $+0.02143 * *$ uptake $0.9700 * *$

YPHP $=1.22+0.964313 * * \mathrm{SP}+0.132731 * * \mathrm{FP}-0.000018 * *$ fruit yield $0.9379 * *$

YPHP $=0.08+0.89643 *$ SP $+0.1218 * * \mathrm{FP}+0.096338 * *$ uptake $0.9385^{* *}$

YPHK $=14.97+0.94761 *$ SK $+0.11056 * *$ FK $+0.00004 * *$ fruit yield $0.9847 * *$

YPHK $=16.01+0.95903 * *$ SK $+0.11338 * *$ FK $-0.04328 * *$ uptake $0.9854 * *$

*Significant at $\mathbf{P}=0.05$; **Significant at $\mathbf{P}=\mathbf{0 . 0 1}$;

PH = Post Harvest; FN, FP and FK = Fertiliser doses of N, $\mathrm{P}_{2} \mathrm{O}_{5}$ and $\mathrm{K}_{2} \mathrm{Oin} \mathrm{kg} \mathrm{ha}^{-1}$. 
Table.2 Observed and predicted post-harvest soil $\mathrm{KMnO}_{4}-\mathrm{N}$, Olsen-P and $\mathrm{NH}_{4} \mathrm{OAc}-\mathrm{K}$ for hybrid brinjal

\begin{tabular}{|c|c|c|c|c|c|c|c|c|c|c|}
\hline \multirow{3}{*}{ Strip } & \multirow{3}{*}{ Treatments } & \multicolumn{3}{|c|}{$\mathrm{KMnO}_{4}-\mathrm{N}\left(\mathrm{kg} \mathrm{ha}^{-1}\right)$} & \multicolumn{3}{|c|}{ Olsen -P $\left(\mathrm{kg} \mathrm{ha}^{-1}\right)$} & \multicolumn{3}{|c|}{$\mathrm{NH}_{4} \mathrm{OAc}-\mathrm{K}\left(\mathrm{kg} \mathrm{ha}^{-1}\right)$} \\
\hline & & \multirow{2}{*}{ Observed } & \multicolumn{2}{|c|}{ Predicted based on } & \multirow[b]{2}{*}{ Observed } & \multicolumn{2}{|c|}{ Predicted based on } & \multirow[b]{2}{*}{ observed } & \multicolumn{2}{|c|}{ Predicted based or } \\
\hline & & & Yield & Uptake & & Yield & Uptake & & Yield & Uptake \\
\hline & \multicolumn{10}{|c|}{ NPK alone } \\
\hline I & NOP0K0 & 193 & 196 & 197 & 16.6 & 18.3 & 18.8 & 215 & 216 & 216 \\
\hline III & N0P2K2 & 246 & 247 & 248 & 40.1 & 37.9 & 38.0 & 274 & 267 & 264 \\
\hline III & N1P1K1 & 263 & 256 & 256 & 39.6 & 40.4 & 40.5 & 272 & 262 & 263 \\
\hline II & $\mathrm{N} 2 \mathrm{P} 2 \mathrm{~K} 2$ & 232 & 237 & 235 & 36.8 & 36.2 & 36.0 & 250 & 255 & 255 \\
\hline \multirow[t]{2}{*}{ II } & N3P3K3 & 241 & 247 & 247 & 31.2 & 39.2 & 39.2 & 268 & 264 & 264 \\
\hline & \multicolumn{10}{|c|}{ NPK+FYM @ 12.5 $\mathrm{tha}^{-1}$} \\
\hline I & NOP0K0 & 196 & 202 & 204 & 17.4 & 17.4 & 18.1 & 219 & 218 & 219 \\
\hline II & N0P2K2 & 218 & 226 & 225 & 36.4 & 30.9 & 32.0 & 263 & 259 & 260 \\
\hline II & N1P1K1 & 232 & 235 & 235 & 33.2 & 34.7 & 35.2 & 258 & 257 & 257 \\
\hline I & $\mathrm{N} 2 \mathrm{P} 2 \mathrm{~K} 2$ & 210 & 218 & 217 & 26.2 & 27.6 & 27.2 & 234 & 241 & 242 \\
\hline \multirow[t]{2}{*}{ I } & N3P3K3 & 221 & 228 & 229 & 29.8 & 31.6 & 31.6 & 238 & 247 & 247 \\
\hline & \multicolumn{10}{|c|}{ NPK+FYM @ $25 \mathrm{t} \mathrm{ha}^{-1}$} \\
\hline I & NOP0K0 & 190 & 201 & 206 & 17.0 & 25.2 & 24.6 & 218 & 230 & 230 \\
\hline I & N0P2K2 & 196 & 208 & 209 & 30.2 & 26.6 & 26.9 & 241 & 245 & 246 \\
\hline I & N1P1K1 & 218 & 219 & 220 & 26.4 & 30.7 & 30.2 & 230 & 240 & 241 \\
\hline III & N2P2K2 & 260 & 268 & 268 & 51.8 & 55.0 & 54.5 & 273 & 286 & 286 \\
\hline \multirow[t]{3}{*}{ III } & N3P3K3 & 277 & 283 & 285 & 52.8 & 61.8 & 61.5 & 277 & 289 & 288 \\
\hline & Mean & 226.2 & 231.4 & 232.1 & 32.4 & 34.2 & 34.3 & 248.7 & 251.7 & 251.9 \\
\hline & 'r' value & & $0.97^{* *}$ & $0.97^{* *}$ & & $0.97^{* *}$ & $0.97^{* * *}$ & & $0.99^{* * *}$ & $0.99 * *$ \\
\hline
\end{tabular}


Table.3 Fertiliser prescription and predicted post-harvest soil test values for hybrid brinjal based on initial soil test values

\begin{tabular}{|c|c|c|c|c|c|c|}
\hline \multirow{2}{*}{$\begin{array}{l}\text { Yield target } \\
\left(\mathrm{t} \mathrm{ha}^{-1}\right)\end{array}$} & \multicolumn{3}{|c|}{ Fertiliser Doses $\left(\mathrm{kg} \mathrm{ha}^{-1}\right)$} & \multicolumn{3}{|c|}{ PHSTV $\left(\mathrm{kg} \mathrm{ha}^{-1}\right)$} \\
\hline & $\mathbf{N}$ & $\mathbf{P}_{2} \mathrm{O}_{5}$ & $\mathrm{~K}_{2} \mathrm{O}$ & $\mathbf{N}$ & $\mathbf{P}$ & $\mathbf{K}$ \\
\hline \multicolumn{7}{|c|}{ Under NPK alone } \\
\hline 50 & 170 & 93 & 112 & 227 & 32.1 & 247 \\
\hline 55 & 208 & 110 & 139 & 231 & 33.6 & 251 \\
\hline 60 & 245 & 127 & 167 & 234 & 35.0 & 255 \\
\hline \multicolumn{7}{|c|}{ NPK+FYM @ $12.5 \mathrm{t} \mathrm{ha}^{-1}$} \\
\hline 50 & 134 & 73 & 83 & 228 & 32.7 & 250 \\
\hline 55 & 172 & 90 & 110 & 232 & 34.7 & 254 \\
\hline 60 & 209 & 107 & 138 & 236 & 36.7 & 258 \\
\hline \multicolumn{7}{|c|}{ NPK+FYM @ $25 \mathrm{t} \mathrm{ha}^{-1}$} \\
\hline 50 & 98 & 53 & 54 & 229 & 37.7 & 257 \\
\hline 55 & 136 & 65 & 81 & 234 & 39.9 & 261 \\
\hline 60 & 173 & 87 & 109 & 239 & 42.1 & 264 \\
\hline
\end{tabular}

ISTV: $\mathrm{KMnO}_{4}-\mathrm{N}=212 \mathrm{~kg} \mathrm{ha}^{-1}$, Olsen-P= $26 \mathrm{~kg} \mathrm{ha}^{-1}, \mathrm{NH}_{4} \mathrm{OAc}=240 \mathrm{~kg} \mathrm{ha}^{-1}$

\section{Fertiliser Prescription Equations}

\begin{tabular}{|l|l|l|}
\hline \multicolumn{1}{|c|}{ STCR-NPK alone } & \multicolumn{1}{c|}{ STCR-IPNS (NPK+FYM) } \\
\hline FN $=\mathbf{0 . 7 5 T}-\mathbf{0 . 9 3 ~ S N ~}$ & FN $=0.75 \mathrm{~T}-0.93 \mathrm{SN}-0.53 \mathrm{ON}$ \\
\hline FP2O5 $=\mathbf{0 . 3 4} \mathbf{T}-\mathbf{2 . 9 7} \mathbf{S P}$ & $\mathrm{F} \mathrm{P}_{2} \mathrm{O}_{5}=0.34 \mathrm{~T}-2.97 \mathrm{SP}-0.83 \mathrm{OP}$ \\
\hline FK2O $=\mathbf{0 . 5 5} \mathbf{T}-\mathbf{0 . 6 8} \mathbf{S K}$ & $\mathrm{F} \mathrm{K}_{2} \mathrm{O}=0.55 \mathrm{~T}-0.68 \mathrm{SK}-0.51 \mathrm{OK}$ \\
\hline
\end{tabular}

FN, $\mathrm{FP}_{2} \mathrm{O}_{5}$ and $\mathrm{FK}_{2} \mathrm{O}$-fertiliser $\mathrm{N}, \mathrm{P}_{2} \mathrm{O}_{5}$ and $\mathrm{K}_{2} \mathrm{O}\left(\mathrm{kg} \mathrm{ha}^{-1}\right)$; T- yield target (q ha $\left.{ }^{-1}\right)$; SN, SP and SK- Alkaline $\mathrm{KMnO}_{4}-\mathrm{N}$, Olsen-P and $\mathrm{NH}_{4} \mathrm{OAc}-\mathrm{K}\left(\mathrm{kg} \mathrm{ha}^{-1}\right)$; ON, OP and OK $-\mathrm{N}, \mathrm{P}$ and K through FYM $\left(\mathrm{kg} \mathrm{ha}^{-1}\right)$ 
Fig.1 Comparison between observed and predicted post-harvest $\mathrm{KMnO}_{4}-\mathrm{N}$, Olsen-P and $\mathrm{NH}_{4} \mathrm{OAc}-\mathrm{K}$ for hybrid brinjal (using yield data)

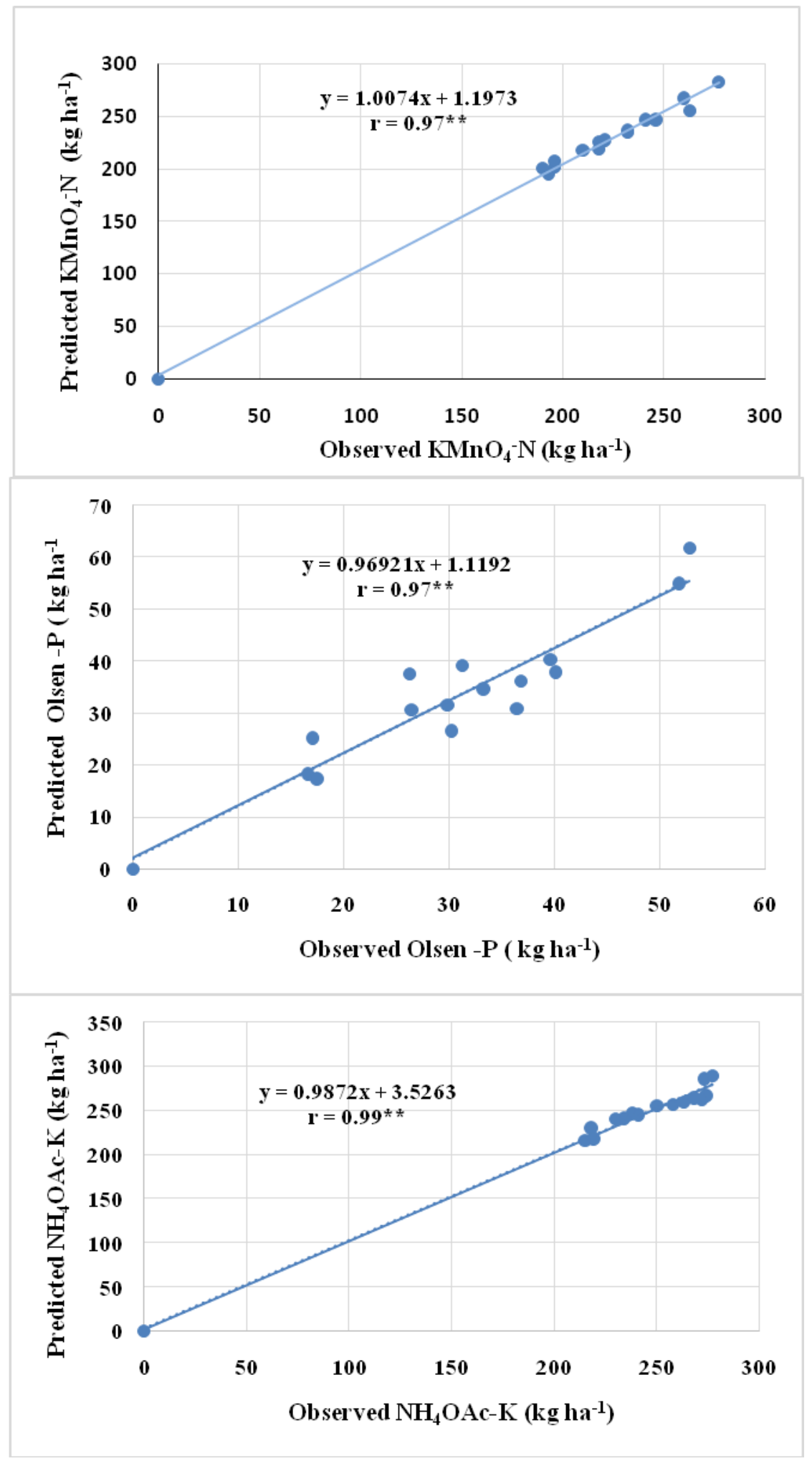


Fig.2 Comparison between observed and predicted post-harvest $\mathrm{KMnO}_{4}-\mathrm{N}$, Olsen-P and $\mathrm{NH}_{4} \mathrm{OAc}-\mathrm{K}$ for hybrid brinjal (using uptake data)

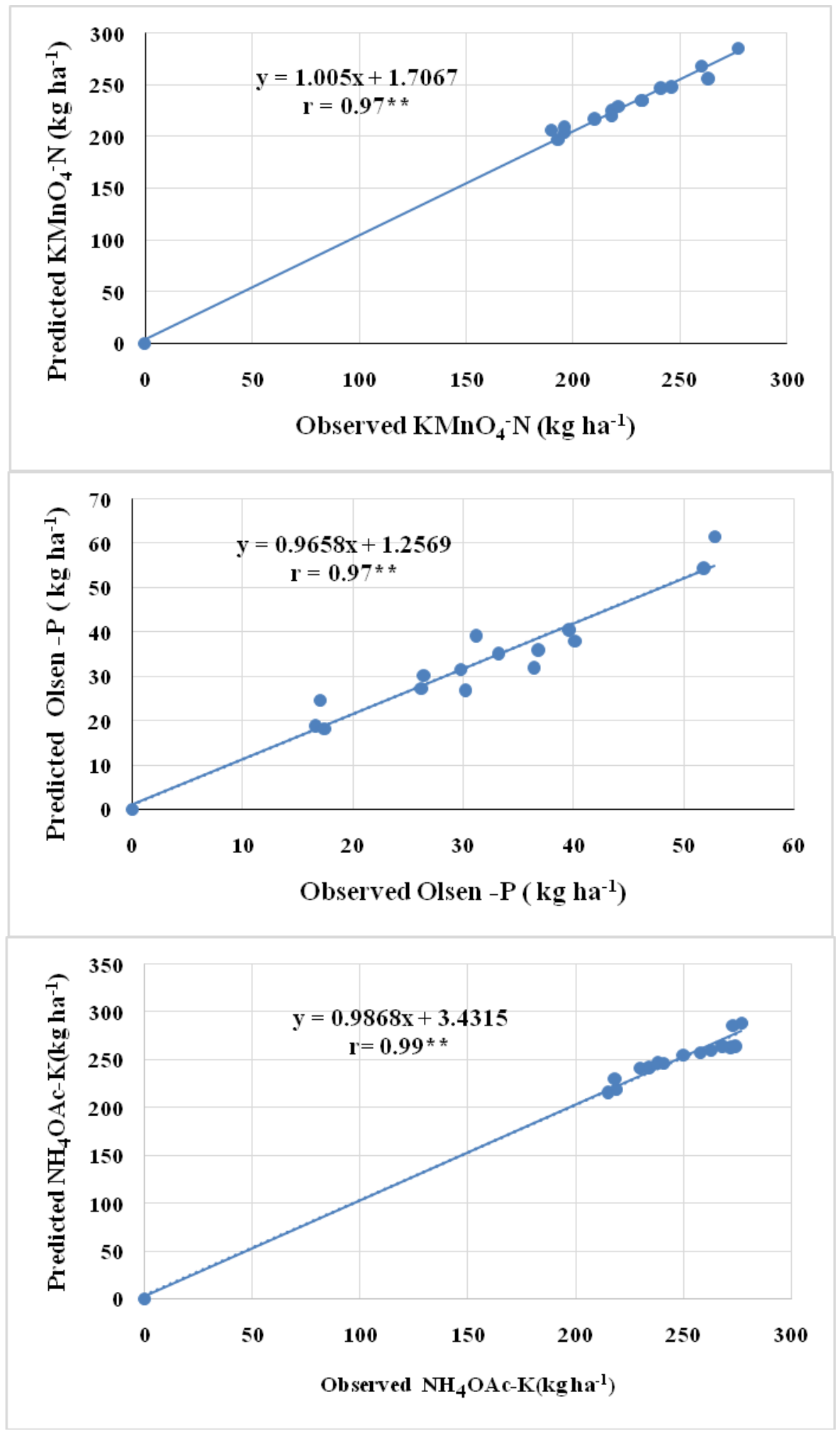


Similarly the post-harvest soil test values were calculated under NPK+FYM @ $12.5 \mathrm{t}$ $\mathrm{ha}^{-1}$ (IPNS) and values were 228,232 and $236 \mathrm{~kg} \mathrm{ha}^{-1}$ of $\mathrm{KMnO}_{4}-\mathrm{N}$; 32.7,34.7 and 36.7 $\mathrm{kg} \mathrm{ha}^{-1}$ Olsen-P and 250,254 and $258 \mathrm{~kg} \mathrm{ha}^{-1}$ $\mathrm{NH}_{4} \mathrm{OAc}-\mathrm{K}$, respectively and also in $\mathrm{NPK}+\mathrm{FYM} @ 25 \mathrm{t} \mathrm{ha}^{-1}$ (IPNS) values were 229,234 and $239 \mathrm{~kg} \mathrm{ha}^{-1}$ of $\mathrm{KMnO}_{4}-\mathrm{N}$; $37.7,39.9$ and $42.1 \mathrm{~kg} \mathrm{ha}^{-1}$ Olsen-P and 257,261 and $264 \mathrm{~kg} \mathrm{ha}^{-1} \mathrm{NH}_{4} \mathrm{OAc}-\mathrm{K}$. The results indicated that irrespective of yield targets, there was either maintenance or builtup of post -harvest soil available N,P and K as compared to the initial status and the magnitude was higher with increasing yield targets. Between NPK alone and IPNS, the magnitude of built-up was relatively higher with IPNS.

The results indicated that irrespective of yield targets, there was built-up of soil available $\mathrm{N}, \mathrm{P}$ and $\mathrm{K}$ and the magnitude was higher with increasing yield targets. Among the three nutrient management practices, the magnitude of built-up was relatively higher with NPK+FYM @25 t ha ${ }^{-1}$ followed by NPK + FYM @12.5t ha ${ }^{-1}$ and NPK alone. This high lightened the significance of IPNS in cropping sequence. Similar type of computing fertiliser recommendations were developed by Santhi and Selvakumari (1998) for rice-riceblackgram, Srivastava et al., (1999) for pigeon pea- wheat and Praveena Katharine et al.,(2013) on Inceptisol and Coumaravel et al., (2013) for maize-tomato sequence on Alfisol.

\section{References}

AlkaArya., Sobhan Singh and PradeepDey 2019. Prediction of post-harvest soil test values and apparent nutrient balance after cauliflower (Brassica oleracea L var.botrytis) in Mollisol.

Andi, K.1998. Soil test crop response studies under integrated plant nutrition system for Bhendi -Sunflower cropping sequence on Inceptisol. $\mathrm{Ph} \mathrm{D}$ Dissertation., TNAU, Coimbatore.

Chandra Sekhar Rao, C and Singh, K.D. 1992. Prediction of post-harvest soil test values after maize-wheat and maizewheat-moong sequences based on initial soil test values. J. Indian Soc. Soil Sci. 40:748-752.

Coumaravel, K., R. Santhi and S. Margatham, K.M. Sellamuthu and A Bhaskaran. 2013. Fertiliser recommendations for maize-tomato sequence on Alfisol. In: Proc. National Seminar on Framing Systems, 19th March, 2013, Annamalai University, Annamalai Nagar, Pp. 5657.

Dey, P. and D.K. Das. 2014. Progress report of the All India Co-ordinated Project for Investigations on Soil Test Crop Response. ISSS, Nabi Bagh, Berasiroad, Bhopal.

Hanway, J.J, Heidal H. Soil analysis method used in Lowa state soil testing laboratory, Lowa Agriculture, American Society of Agronomy. 1952; 57: 10251027.

Piper, C.S.1966. Soil and plant analysis. Hans publications, Bombay.

Olsen S.R., C.V. Cole, F.S. Watanbe and L.Dean.1954.Estimation of available phosphorus in soils by extraction with sodium bicarbonate. U.S.D.A. Circ. 939. U.S. Govt. Printing Office, Washington, DC.

Praveena Katharine, S., R. Santhi, C., Chandrasekhar, S. Margatham and K.M. Sellamuthu 2014. Evaluation of STCRIPNS recommendation for transgenic cotton on Inceptisol. Res. Crops. 15(1): 226-231.

Ramamaoorthy, B., R.K. Narasimham and R.S. Dinesh. 1967. Fertiliser application for specific yield targets on Sonara 64(wheat). Indian Fmg., 17:43-45.

Ramamoorthy, B., R.K. Agarwaland K.D. 
Singh. 1971. Soil fertility management under multiple cropping. Indian Fmg., 21(6): 50-52.

Santhi, R. and G. Selvakumari. 1998. Prediction of post-harvest soil test values and fertiliser calibrations for a rice based cropping sequence under integrated plant nutrition system. Oryza, 35(3): 246-251.

Sarvesh Kumar, Sobhan Singh, Poonam Gautham, Poonam Gangola and Vinnet Kumar. 2018. Prediction of post-harvest soil test values and apparent nutrient balance for turmeric (Curcumin longa L.) in Mollisol of Uttarakhand. Int.J.Curr.Microbiol.App.Sci special issue (7): 4353-5358.

Srivastava, S., K.D. Singh and A. Subba Rao. 1999. Fertiliser recommendations for pigeonpea-wheat cropping system based on initial soil test values. J. Trop. Agric. 7(1-4):83-89.

Subbaiah, B.V and G.L Asija. 1956. A rapid procedure for estimation of available nitrogen in soils Curr. Sci., 25: 259-260. Timsina, J., U. Singh, M. Badaruddin and C. Meisner. 1998. Cultivar, nitrogen and moisture effects on a RW sequence experimentation and simulation. Agron. J. 90: 119-130.

\section{How to cite this article:}

Kirankumar, Ch., R. Santhi, D. Srihari and Maragatham, S. 2019. Fertilizer Calibrations for Hybrid Brinjal based Cropping Sequence using Post-Harvest Soil Test Values Prediction Equations under Soil Test Crop Response Based Integrated Plant Nutrition System. Int.J.Curr.Microbiol.App.Sci. 8(07): 2051-2061. doi: https://doi.org/10.20546/ijcmas.2019.807.246 